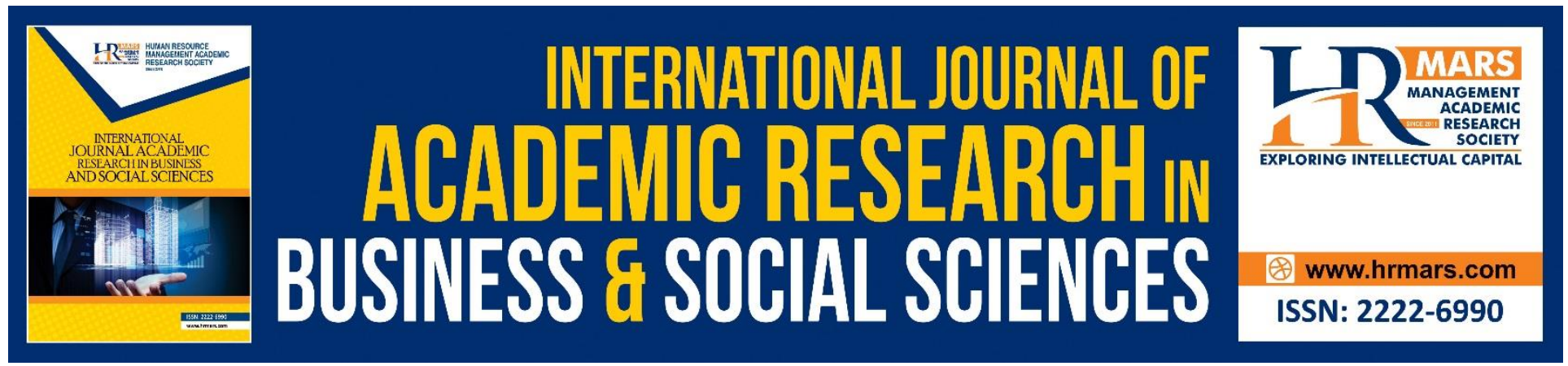

\title{
Transformational Leadership: A Review on Contemporary Issues
}

\section{Sultan Saqar Oqaidan Alwahaibi}

To Link this Article: http://dx.doi.org/10.6007/IJARBSS/v9-i3/5804

DOI: $10.6007 /$ IJARBSS/v9-i3/5804

Received: 29 Jan 2019, Revised: 10 Feb 2019, Accepted: 29 Feb 2019

Published Online: 24 March 2019

In-Text Citation: (Alwahaibi, 2019)

To Cite this Article: Alwahaibi, S. S. O. (2019). Transformational Leadership: A review on contemporary issues. International Journal of Academic Research Business and Social Sciences, 9(3), 1398-1413.

\section{Copyright: (C) 2019 The Author(s)}

Published by Human Resource Management Academic Research Society (www.hrmars.com)

This article is published under the Creative Commons Attribution (CC BY 4.0) license. Anyone may reproduce, distribute, translate and create derivative works of this article (for both commercial and non-commercial purposes), subject to full attribution to the original publication and authors. The full terms of this license may be seen

at: http://creativecommons.org/licences/by/4.0/legalcode

Vol. 9, No. 3, 2019, Pg. 1398 - 1413

http://hrmars.com/index.php/pages/detail/IJARBSS

JOURNAL HOMEPAGE

Full Terms \& Conditions of access and use can be found at http://hrmars.com/index.php/pages/detail/publication-ethics 




\title{
Transformational Leadership: A Review on Contemporary Issues
}

\author{
Sultan Saqar Oqaidan Alwahaibi \\ Othman Yeop Abdullah Graduate School of Business, \\ Universiti Utara Malaysia, Sintok-Kedah, Malaysia \\ Email: sultan_saqar@oyagsb.uum.edu.my
}

\begin{abstract}
The primary objective of this review is to comprehensively delve into recent studies that are directly related to Transformational Leadership (TFL). Transformational theory explains and concentrates on a community-oriented follower-leader engagement as well as defining leadership as broader than event-oriented exchanges among leaders and followers. New concerns are recognized, new skills and capabilities are developed. However, there are limited studies that investigated the importance of how to improve TFL competences. Specific aspects of training and development of transformational leadership in a variety of contexts needs to be more clearly considered by future studies. The findings of this review clearly reveal that the basis of TFL dimensions is related to followers' development. Furthermore, future studies should continue to examine the causative details surrounding TFL training and development to clarify such relationships that might be exposed. Managerial level training might prove to be both more effective to influence and inspire follower to ease change implementation and cost- effectiveness. Corresponding, supports training in TFL will enhance performance. Therefore, performance suggests that leaders be trained such that they will appear more transformational in order to give useful and important returns on investment in term of follower development. This review revealed that various variables influenced by TFL are not just theoretically sound, but, indeed, empirically proven to be correct. This review has applicability to any aspiring leader, seeking to develop their capacities in an organizational setting.
\end{abstract}

Keywords: Transformational leadership (TFL), Commitment, Work engagement, Job satisfaction, Learning Achievement, Creativity, Innovation, Culture, Team effectiveness, Performance.

\section{Introduction}

Burns (1978) presented a descriptive research concept on Transformational Leadership (TFL) which was further researched by Bass (1985), he shifted leadership approach to organizational domain from political area. In order for organizations to survive in the face of active and changeable society they must adapt to these series of fluctuations. 
In the definition of James MacGregor Burns, a renowned Leadership theorist, transformational leadership is "A relationship of mutual elevation and stimulation that converts followers into leaders and may convert leaders into moral agents." Transformational theory lay emphases on a communityoriented leader-follower engagement. This means that there is a mutually enriching partnership between followers and leaders and consequently focused on motivating and inspiring one another. In Psychology, transformational leadership happens to be among the theories that created the highest number of studies, and in numerous social psychology research, that productivity has been shown (Bass \& Riggo, 2006). In addition, good transformational leaders are leaders who have an extensive understanding of environment and ensure sustainable change. Transformational leadership style has a stronger emphasis on relational, shared, and global perspective where especially the interaction between follower and leader are key components. Furthermore, Bass and Riggo (2006) stated that there are four elements of transformational leadership comprising:

(a) Idealized Influence (II),

(b) Intellectual Stimulation (IS),

(c) Inspirational Motivation (IM), and

(d) Individualized Consideration (IC).

They explain each component of five "I"s of transformational leadership in more details. First, Idealized Influence is that behaviours makes followers wanting to take their leaders as role models. The followers, in this context, tend to recognize with their leaders, and they want to match their leaders apart from respecting, trusting, and admiring them. Extraordinary capabilities and persistence are part of qualities followers considers in their leaders. Consistency and risk taking are also traits exhibited by leaders who are in the class of Idealized Influence. Because they are people of good ethical conducts and high moral standards, whenever right things are to be done, they are usually counted on.

Second, Intellectual Stimulation is the behaviour which encourages creativity and innovation by reframing problems, questioning assumptions, and a situation where new ways approaches are employed for old conditions. Furthermore, leadership that adopts the style encourage creative solutions and new ideas from followers. When mistakes are made by a member, criticism from the transformational leadership is not done in public. Likewise, when the leader has a different viewpoint, ideas from members are not criticised.

Third, Inspirational Motivation is that transformational leader inspires those around him by giving challenge and meaning to their followers' effort through specifically determined behaviours. This type of leadership also provokes working in a team, optimism and also enthusiasm. Transformational leader involves those who follow him by obviously expressing the defined expectations which they should meet and reveal seriousness to the general vision. Leaders who are transformational in nature carries along their subordinates through the process of communication of stated expectations to be met by followers. The followers thereby show a good level of commitment to a shared vision.

Fourth, Individualized Consideration is that individual acts as a mentor or a coach, transformational leader show commitment to every follower's needs for development. Individualized consideration arises when innovative opportunities to learn are generated in association with an environment that is supportive. Generation of new opportunities to learn in a conducive environment usually give rise to individualized consideration. The ability of being an effective listener that appreciates the 
individual differences among employees is one of the traits of transformational leaders. Moreover, two-way communication is stimulated, and personalized connections with the followers occur. Moreover, connections with followers are personalized resulting to a stimulation of two-way communication. A viable means of improving followers is for the individualized leader to accomplish some tasks by delegating them to followers. In order to assess level of progress, tasks that were delegated are periodically checked. This also give the opportunity to know if the followers require further direction and support. Furthermore, individualized consideration is also alike to the term known in the leader-member exchange theory, mainly the core conceptual components (Antonakis \& House, 2002).

\section{Methodology}

In order to get related studies on the concept of transformational leadership, a series of research resources were combed which include Google scholar, Research Gate, Science Direct, and Eresources Log in the Library of University Utara Malaysia searches about Transformational Leadership in the period between 1978 and 2016.

Keywords such as transformational leader or leadership were searched for in the abstract. A great effort was also made in consulting specific studies that are related to these labels. Further studies were also established by looking at the reference list in relevant literature reviews. Series of citations contained in many studies were additional examined whenever an article is located. This procedure identified 60 relevant studies. Exclusion criteria were employed to unpublished materials (for example, master's theses and Ph.D. dissertations) and studies that the author was unable to access.

\section{Transformational Leadership Literature: Issues}

As contained in the references in relation to sixty (60) articles, together with information on numerous variables investigated related to the transformational leadership styles besides brief summary of findings and future study. This review discusses critically the major issues that impacted by transformational leadership (TFL).

\section{Commitment}

Transformational style has increasingly been encouraged for the advantages of individual teacherprincipal school relationship (McCormick, 2004, as cited in Ling and Ling, 2016). Likewise, TFL is directly impacting on teacher commitment and also have indirect impact through teacher efficacy. Moreover, collective teacher efficacy had been highly impacted by TFL which predicted community partnerships through teacher's commitment. The values of members in an organisation are usually increased through TFL by achieving organizational goals when they jettison self-interest and aligning their desire to organizational preferences (Ross \& Gray, 2006). Teachers' commitment to their career is also increased through TFL, which brings about positive effect on academic performances of students. Additionally, Ling and Ling (2016) pointed out that in order to improve the level of teachers' commitment TFL is significantly important for school principals to possess this style. Furthermore, Ibrahim (1998 cited in Ling and Ling, 2016) stated that students' achievement, school achievement quality, and teachers' commitment are greatly impacted by principal's leadership. 
Another study conducted by Selamat, Nordin, and Anida (2013) found that when principals make much effort in developing people, setting direction, and redesigning the school organization, TFL behaviour arises. Tobing (2009, as cited in Atmojo, 2015) illustrated that TFL significantly have impacts on the commitment of organization. Also, Atmojo (2015) stated that, for knowing the effect of TFL towards organizational commitment, there is the need for a vision to be conveyed via inspiration and persuasion, but not through directive and decision statement. Indeed, good and efficient TFL leaders apply a mixture of metaphors, appealing rhetoric, slogan, rituals and symbols because vision commitment is greatly associated with the trust that the subordinates have in those who lead them. Similarly, Kim and Kim (2014) discussed the influence of TFL around the capability to formulate a new vision capable of leading to change in organization. It is expected of a leader to build the commitment of the organizational on the follower by generating the trust of the follower. Indrawati (2014) asserted that inspirational leader in a workplace has the capability to lure subordinates to employ themselves over and above their own self-interest and expectations.

Subordinates have to have confidence and trust in the leader. The positive effect of the TFL is that it promotes organizational effectiveness. For instance, organizational citizenship behaviour, job satisfaction, and organizational commitment. In line with this, Bass and Avolio (1993) exposed that through TFL leadership process can impact followers' commitment by encouraging them to think creatively and critically. Additionally, Walumbwa and Lawler (2003) posited that when followers are the given opportunity to solve problems creatively and understanding their desires, transformational leaders can enhance followers' organizational commitment and motivation. Additional studies showed that charisma can impact significantly on commitment and satisfaction of followers which aids the explanation of the distinct effect of various dimensions of transformational leadership on employee's work psychological attitudes and empowerment (Mei \& Ying, 2015).

\section{Work engagement}

TFL has main effect on both organizational performance and individual performance, and also on work engagement (Bakker et al., 2012). This association between dependent and independent constructs (individual TFL-Job Performance) is not a significant one. This implies that work engagement is full mediation. That finding is consistent with Tims, Bakker and Xanthopoulou, (2011) who have found that TFL and work engagement are positively interrelated on day-level basis. Hence, a significant skill of leader has to be obviously seen as the capability to interact with the followers and others in a manner that will be beneficial. This will make it easy the two parties to have mutual and common understanding. Consequently, there is a correlation between leadership and communication (Al-bogami, 2015).

However, it has been revealed by scholars that there exits strong associations between personal thought at high levels and employee work engagement with attention of employees' job, to get so, transformational leader coaches followers such that they will look and appear responsible, thus, increasing the psychological meaningfulness of the followers (Al-bogami, 2015).

\section{Job satisfaction}

Despite the fact that job satisfaction is subjective in nature, Tondok dan Andarika (2004, as cited in Atmojo, 2015) stated that TFL indicate a significant and positive impact towards job satisfaction. 
Additionally, Atmojo (2015) asserted the transformational leadership impact on job satisfaction that might facilitate vision achievement. Moreover, in order to positively impact employee's performance and morale, understanding and knowing the leadership qualities that will gear up employee's job satisfaction. Besides that, Gill, Flaschner, \& Shachar (2006) argued that through the application of TFL, firms tend to bring reduction to job burnout and stress.

In contrast to the result of a study by Sudarmasto (2005, as cited in Mirkamali, Thani, \& Alami, 2011), which concluded that job satisfaction is not significantly affected by TFL. Whereas, Raj et al., (2016) revealed a moderate connection between teacher' job satisfaction and TFL. The consequences of their research is that the findings are inconsistent with the results of the earlier studies which presented that the practices of TFL by school principal as one of the major determinants of teachers' job satisfaction (Zeinabadi \& Rastegarpour, 2010).

However, in order for the leader to achieve organization objectives must provide encouragement to the followers. In order to use individualized consideration effectively the leader's responsibility and ability in increasing the followers' satisfaction level and motivate their productivity. It is expected of a leader to act informally, friendly, and close to the followers by providing advice and treat them equally, support and help them for personal growth.

\section{Learning achievement}

TFL can play fundamental role in addressing student learning achievement. According to Amin and Yusof (2012), many leadership practices are associated with the learning achievement and the performance of student. Additionally, Aliakbari and Darabi (2013) demonstrated a positive significant association between the style of TFL, classroom supervision efficacy, and personality factors. In line with the management of the classroom, it is mandatory for teachers to own some leadership capability with a view to identifying the way by which students will be encouraged. Therefore, one of the causes why schools fail to gained their institutional objectives is due to inappropriate style of leadership. Also, teachers themselves do not see themselves as being leaders. In addition, Mirkamali et al., (2011) found that the most factors which predict organizational learning are TFL components such as idealized influence and individual consideration besides responsibility and nature of work. Additionally, Khany and Ghoreishi (2014) posited that higher sense of responsibility that increases students' learning urge and also assists them to achieve their academic goals can be achieved through high TFL styles. That means, this is directly useful for teachers and other educational practitioners. For quality improvement of teaching and learning, it will help teachers to concentrate on characteristics of individual students. Their findings revealed that a significant association exits between teachers' efficacy of classroom management and the TFL style of teachers with reflective thinking. Also, Allameh, Heydari, and Davoodi (2012) discussed education and the importance of leadership in it. They explained that it involves assigning power and operational autonomy to teachers in such a way that they have calculated and crucial opportunity of developing students' learning ability.

Such improvement will be happened when a leader able to strengthen sense of group purposefulness, transfer sense of self-confidence, enhance job perspectives, facilitate proper thinking models to teachers, think out of the box about old problems with contemporary methods, 
these techniques will bring about an environment that supports independence, competency feelings, meaningfulness and effectiveness.

Furthermore, TFL is a key aspect of investment on human capital in a firm thus create overall value. These leaders, by strongly encouraging their employees' creative and innovative behaviours and enhance member leader exchange, which are broadly considered as a measurement of human capital (Birasnav, Rangnekar, \& Dalpati, 2010). So, transformational leaders who trust employees, empower subordinates to be part of decision making process of the organization. This increases self-efficacy and innovative behaviours of the employees', and these factors are suitable potential to impact employees' human capital benefits which will lead to improved career advancement and higher returns on investments (Birasnav et al., 2010).

Hence, organizations with an objective to generating intellectual capital, needs to put in place for their leaders a TFL style training program. It is worthy of noting that because of intellectual simulation feature, the leaders should be encouraged to undergo every task that teaches the values and beliefs of an organization.

A transformational leader plays in a way to model behaviours, as a proactive person and perceived as an example for the subordinates. This sort of leader inspires the subordinates by challenging them to exceed their boundaries, to look for creative resolutions for the difficulties to facilitate the overall organizational goals. Thereby, leader pays attention to the needs of goal-attainment and professional development of each subordinate, encouraging them to improve fully their competences (Castanheira \& Costa, 2015).

As well, Olcum and Fayda (2015) explained the dynamics of TFL that involve subordinates having a shared vision for the future, and the capacity to work collectively for the assistance of the group, and a strong personal identification with the leader. So, leaders should be admired and respected by subordinates in order to transform their organizations. However, Mirkamali, Thani, and Alami (2011) stated that TFL usually plays a significant role to play in fostering knowledge, application of knowledge in an organization and stimulating organizational leadership. Transformational leaders pay significant attention to effective communication, value sharing and they also have an interactive vision, thereby enhancing a proper environment for innovative teams. Additionally, leaders should have a strong influence on the distribution and acquisition of information. Moreover, leaders enhance collective processes of organizational learning, favourable attitudes toward creativity and proactivity, and mutual trust between leaders and members.

Recently development in a strategic thinking leadership which goes with a wide-ranging plan, integrating short-range outcomes plus the long-term focus. The impact of the effort of such leader cascades across the entire organization. Therefore, the what, the how, and the who of strategic leadership intertwined with TFL (Asiya, Kazmi, Naarananoja, \& Kytola, 2016).

\section{Creativity}

A key factor is outstanding leadership in the context of jobs which tend to encourage followers' participation of followers is creative course. First, Qu, Janssen, \& Shi (2015) investigated relations that exits between TFL and followers creativity. This was done by moderating and mediating the role of leader creativity expectations and follower relational identification respectively. The outcome was 
positive significantly by making use of relational identification theory to justify that as part of their self-concept, TFL can help in the internalization of the followers' role association with their leader. Whereas, Shin and Zhou (2003) concluded that in the connection between TFL and follower creativity, intrinsic task motivation is an indispensable mediator. Also, Gumusluoglu and Ilsev (2009) suggested that TFL behaviours are probable to act as forces that can promote creativity. Precisely, followers can be motivated and their creativity enhanced by making use of intellectual stimulation. This will help those who are following to challenge the fundamental underlying assumptions of the recognized thought framework and also consider the previous problems in different dimensions.

Likewise, Chatterjee and Kulakli (2015) concluded that TFL behaviours has a strong correlated with emotional intelligence than did the transactional leadership behaviours by employing the connection of leadership and emotion. Follower ratings of TFL behaviour were positively interrelated to those leaders characterized as self-aware. Besides that, Sharma, Nagar, and Pathak (2012) stated that transformational leaders motivate subordinates' imaginations and thoughts, identify the creative mind set and develop the capabilities of individual subordinate and work teams, deliver support and resources and give the subordinates choice to independently act, and motivate the spirit of hard work toward attaining great targets, which could all support the self-views of the followers for being creative. Additionally, according to Esfahani and Soflu (2011) who asserted that personal considerations is the strongest predictive construct in TFL method and among emotional intelligence. Their results have shown that transformational leaders possess extra ordinary skills for accomplishing organizational goals by encouraging motivation and instilling optimum self confidence in their followers.

Such characteristics of living by example usually have a great influence on subordinates, which make them to attribute an extremely positive and strong abilities to the leader. As a result, followers appreciate and internalise the values and believes of such a leader. Thus, studies indicated that employee's creativity is not necessarily related to TFL.

\section{Innovation}

Nowadays, rising global competition is leading to growing demand for various products and increased uncertainty. So, organizations are giving keen interest to exploratory innovation emphasis continually, new knowledge of services and products and development for emerging markets and customers. Alternatively, organizations focus on exploitative innovation emphasising on extension of existing services and products and existing knowledge resources in recent markets. There is an indication about the effect of TFL and transactional leadership on exploitative innovation and exploratory innovation at the level of organization (Ebrahimi, Moosavi, \& Chirani, 2016). In line with this topic, Gutiérrez-Gutiérrez (2012) examined TFL impact on the performance of organizational through dynamic competences of organizational innovation and learning, investigating 168 Spanish companies. The result showed that by applying learning and organizational innovations, the impact of TFL on organizational performance is significantly positive. Furthermore, İşcan, Ersarı, and Naktiyok (2014) concluded that transformational leaders has great impact on subordinates whose engagement is immensely required for implementation of organizational performance and innovation. As well, in another research, Jansen, Vera, and Crossan (2009) presented that TFL behaviours play a significant function in adjusting with constructive thinking. This is followed by the process of exploratory 
INTERNATIONAL JOURNAL OF ACADEMIC RESEARCH IN BUSINESS AND SOCIAL SCIENCES Vol. 9, No. 3, March, 2019, E-ISSN: 222 2-6990 @ 2019 HRMARS

innovation. They concluded that the association between innovation and leadership and its effect on the performance of organizational involve knowledge of environmental dynamics as an example of mediating variables.

However, since innovative behaviour is a condition to reach competitive advantage. Consequently, private sector employees observe creation of human capital with the enhancement of their transformational leaders. Contrarily, many TFL in the organizations that are public are dissimilarly to engage in the events that are risky and required to accomplish as transactional leaders.

\section{Culture}

Culture forms are the basis of shared thought and group identity, feeling and belief. One of the most significant functions decisive of leaders, mostly the founders of a company is the creation of culture and managing it. Most organizational observers and researchers by now consider that organizational culture has a powerful influence on long-term organizational performance and organizational effectiveness. Furthermore, culture has its roots from competencies and leadership style imposed in organizations.

In this vein, Muenjohn and Armstrong (2015) studied the connections between leadership characters displayed by expatriate managers and cultural values of the employees of host-nations. Their findings were TFL behaviour was highly positively correlated with employees' extra effort, satisfaction, and effectiveness. Moreover, on the basis of the statistical data obtained from Taiwan and U.S Spreitzer, Perttula \& Xin, (2005 as cited in Allameh, Heydari, \& Reza Davoodi, 2012) concluded a relationships between TFL and leadership effectiveness, cultural value has a main role to play.

In a research by Bass (1997) believed that TFL should travel well across cultures. TFL can be regarded as one of aspect of worldwide leadership model. So, he came up with a model containing two important forces in achieving TFL globally. The forces are external and internal-driven forces. The external-driven force denotes externally driven environmental factors that tends to give rise to the perceptions of TFL as a global phenomenon.

The Internal-driven forces on the other hand consists of four vital components: functional universal, simple universal, flexibility, and universal systematic behaviour.

The first factor is to enhance interpersonal associations with the host-nation followers. It also occurred as a significant factor in the workings of a successful expatriate leaders (Jordan and Cartwright, 1998). If transformational expatriates make use of these positive relationships, they will able to understand better the behaviours of their subordinates and a well-grounded understanding of the cultural differences of the host nation.

According to Jati, Hassan, Harman, Jabar and Majid (2015) external environment, flexibility and change are impact organizational development culture through leadership style. Additionally, Keow (2011) found that TFL play major role to facilitate and encourage the cultural changes. In addition, Yıldırım and Birinci, (2013) argued that TFL and culture stand as a strong point for accomplishing the desired business outcomes during major organizational changes such as acquisitions and merger.

Besides that, Jantzi and Leithwood (1996) who suggested to increase school culture, transformational leader maintain collaboration and foster the improvement of staff knowledge and skills besides helping employees to solve problems together effectively. Another point that increase TFL effectively is employees' trust which is one of the most critical process to gain leader's influencing (Alger, 2008). 


\section{Team Effectiveness}

Zhang, Li, Ullrich, and van Dick (2015) argued that transformational leadership, based on dual-level TFL model, contains of two parts: the first part is group focused which includes leadership behaviours that inspire subordinates to track the common futuristic vision and transform their values. In fact, this brings motivation to all group members to achieve their organizational objectives and expectations. Individual focus is the second part and it entails leader's behaviours which are distinct to a specific leader-follower dyad.

Hence, Zhang,et al (2015) suggested that these processes are capable of creating group-level outcomes that are divergent. Precisely, when the behaviours of leaders are channelled toward the group, beneficial effect leads to the effectiveness of the team. Contrarily, if it happens that leaders give a distinct attention and concentration to few selected people, it can have an unintentional consequence of bringing the effectiveness of the team to a lower level.

Moreover, García-Guiu, Moya, Molero and Moriano (2016) highlighted the importance of TFL style which has positive relationship with the group potency. They also analysed the indirect associations between TFL and group cohesion and identification. The study revealed that the later construct performed a mediating role between TFL and group potency. The assumptions become essential because of the increasing necessity of TFL and actions applied at lesser lower command chain levels for the accomplishment of security mission of organizations. Hence, the concept of group potency is described as "the collective belief in a group that it can be effective". Also, the relationship between cohesion and TFL has been investigated in many studies. These studies emphasized the impact of cohesion on unit performance and collective-efficacy performance of team.

However, TFL helps organizational authority to improve strategies, to assess, to analyse, and find solutions to very complex problems, such as, strategic cost analysis, value chain analysis, analytical techniques through the use of competitive strength assessment and SWOT analysis. To support the fact that to achieve operational effectiveness, seamless process of organizational transformational together with productivity is likely to happen if there is judicious utilization of human resources through appropriate selection process and skill development of smart or optimal teams (Kazmi \& Naaranoja, 2015).

In addition, if a high level TFL climate is put in place, collective trust that followers have in the leadership personnel of an organization and great degree of trust can increase. Support and eventually, organizational performance are increased. Some particular TFL behaviours brings about personal identification with the leader while some behaviours bring about social identification with the group, this is a dual effect of TFL. Thus, there is a distinction outcomes between the different TFL dimensions (Boehm, Dwertmann, \& Bruch, 2015).

\section{Performance}

To enhance employee and organization performance, TFL improves adequate relationship with followers and inspires employees to think beyond their personal wants for organization and group interest. Ultimately, business potential performs more profitable tasks which means customized services and goods, high quality production, and high performance (Khoshlahn \& Sattari, 2016).

In the contemporary organizations, employees on junior and senior cadre are predictable to be prepared with a leadership capacity that is proactive. Such as a communication and thought patterns 
are a critical aspect that impact the TFL quality (Gökalp et al., 2010). Moreover, (Pourbarkhordari et al., 2016) emphasised on the enhancement of the subordinates' involvement, and stimulates them to be energetic to their work, TFL with subordinates care aids them to record meaningful achievement in their career advancement and prepare the junior officers to take the responsibilities attached to leadership and develop their endowment. So, researchers have argued that there is strong connection between TFL and employee work results like job performance that ultimately increase the performance of organization.

It has to be mentioned that in the recent time, the leadership in academics have differentiated groupfocused TFL from individual-focused. They claimed that TFL has effects on both group and individuallevel results (Pourbarkhordari et al., 2016). Certainly, the Individual-focused TFL assumes that a leader can has different behaviours towards individual subordinate. The individual-level viewpoint can do some kind of speculation to enable subordinates to improve their capabilities and develop their individual talents. Therefore, TFL changes the structural characteristics of subordinate's jobs with stating the importance of vision and supporting followers to move above their personal welfares to achieve job performance enhancement. Majority of leaders in academic have been perceived to be using TFL leadership style, because employees can perform better when the organizational TFL style used and also easily share their knowledge among themselves (Wahab, Rahmat, Yusof, \& Mohamed, 2016).

Obviously, creating such organizational vision to accomplish organizational performance involve strong leadership, sharing the same viewpoint that TFL is more active than transactional leadership for organizational development, while that the participative style is more productive in any environment and culture (Samad, 2012). On contrast, the study of Sim, (1997, as cited in Samad, 2012) asserted that there exit no best style of leadership in all situations and it is difficult to fix the best leadership style for organizational performance.

In addition, Bennis \& Nanus (1985, as cited in Allameh, 2011) stated in a study that took them five years that talents of subordinates can be improved through TFL by assigning different tasks to them. Conversely, managers' leadership style is not well-matched with the characteristic of the individual consideration. While, direct and meaningful relationship occurs between organizational outcomes and characteristics of TFL style. This is because workers can conveniently share their individual knowledge among themselves and perform better when the organizational TFL style used. (Wahab, Rahmat, Yusof, \& Mohamed, 2016).

Also in the original conceptualization of TFL (Bass, 1985), the core component was charisma. Over the past 30 years there is significant proof which confirms that their exits a relationship between unit level performance and TFL (Boehm et al., 2015).

There are numerous studies to support the assertion that leaders are perceived effective when they use both transactional and transformational leadership styles. In Contrast, the leaders who are using laissez-faire or passive leadership style are considered to have negative effect on their subordinates' productivity and outcomes (Asrar-ul-haq \& Kuchinke, 2016). Whereas, Ayoubi and Khalifa (2015) asserted that it is subordinates demographics that causes significant variances in leadership styles, not sector. This result agrees with the results of Carless (1998) who concluded that male managers were less transformational than female managers. 
INTERNATIONAL JOURNAL OF ACADEMIC RESEARCH IN BUSINESS AND SOCIAL SCIENCES

Vol. 9, No. 3, March, 2019, E-ISSN: 222 2-6990 @ 2019 HRMARS

\section{Conclusion}

This review has discussed the main issues which are affected by TFL. The study begins with brief definition and components of TFL. Followed by categorizing the series of literatures to give an easy analysis and reference earlier research findings. The study synthesised previous literature on TFL and discussed a set of variables that have been investigated with TFL such as, organizational commitment, work engagement, job satisfaction, learning achievement, creativity, innovation, culture, team effectiveness, and organizational performance. The review findings revealed that limited studies had examined the influence of training and development on TFL (Aliakbari \& Darabi, 2013; Atmojo, 2015).

\section{References}

Al-bogami, H. M. Z. (2015). The Relationship between Transformational Management and Communication Skills among Heads of Departments of KAU. Procedia - Procedia Computer Science, 65(Iccmit), 1160-1164. https://doi.org/10.1016/j.procs.2015.09.026

Alger, G. (2008). Transformational leadership practices of teacher leaders. Academic Leadership: The Online Journal, 6(2), 19.

Aliakbari, M., \& Darabi, R. (2013). On The Relationship between Efficacy of Classroom Management, Transformational Leadership Style, and Teachers' Personality. Procedia - Social and Behavioral Sciences, 93(2008), 1716-1721. https://doi.org/10.1016/j.sbspro.2013.10.105

Allameh, S. M. (2011). Considering transformational leadership model in branches of Tehran social security organization. Procedia - Social and Behavioral Sciences, 15, 3131-3137. https://doi.org/10.1016/j.sbspro.2011.04.259

Allameh, S. M., Heydari, M., \& Reza Davoodi, S. M. (2012). Studying the relationship between transformational leadership and psychological empowerment of teachers in abade township. In Procedia - Social and Behavioral Sciences (Vol. 31, pp. 224-230). https://doi.org/10.1016/j.sbspro.2011.12.046

Amin, N. H. M., \& Yusof, M. M. (2012). Head of Program's Leadership Style and Academician's Perception towards Higher Learning Institution Students' Academic Achievement. Procedia Social and Behavioral Sciences, 65(ICIBSoS), 821-826.

https://doi.org/10.1016/j.sbspro.2012.11.205

Antonakis, J., \& House, R. J. (2013). The full-range leadership theory: The way forward. In Transformational and Charismatic Leadership: The Road Ahead 10th Anniversary Edition (pp. 3-33). Emerald Group Publishing Limited.

Asiya, S., Kazmi, Z., Naarananoja, M., \& Kytola, J. (2016). Integrating strategic thinking and transformational leadership for NPD idea support process. Procedia - Social and Behavioral Sciences, 229, 387-397. https://doi.org/10.1016/j.sbspro.2016.07.149

Asrar-ul-haq, M., \& Kuchinke, K. P. (2016). Impact of leadership styles on employees ' attitude towards their leader and performance: Empirical evidence from Pakistani banks. Future Business Journal, 2, 54-64. https://doi.org/10.1016/j.fbj.2016.05.002

Atmojo, M. (2015). The Influence of Transformational Leadership on Job Satisfaction, Organizational Commitment, and Employee Performance. International Research Journal of Business Studies, 5(2), 113-128. Retrieved from http://www.irjbs.com/index.php/jurnalirjbs/article/view/82

Ayoubi, R., \& Khalifa, B. (2015). Leadership Styles at Syrian Universities and the Differences Caused 
INTERNATIONAL JOURNAL OF ACADEMIC RESEARCH IN BUSINESS AND SOCIAL SCIENCES Vol. 9, No. 3, March, 2019, E-ISSN: 2222-6990 @ 2019 HRMARS

by Sector and Follower Characteristics. Arab Economic and Business Journal, 10(1), 1-8. https://doi.org/10.1016/j.aebj.2014.11.001

Bakker, A. B., Demerouti, E., Ten, B., \& Lieke, L. (2012). Work engagement, performance, and active learning: The role of conscientiousness. Journal of Vocational Behavior, 80(2), 555-564. http://dx.doi.org/10.1016/j.jvb.2011.08.008

Bass, B. M. (1985). Leadership and performance beyond expectations. Collier Macmillan.

Bass, B. M. (1997). Does the transactional-transformational leadership paradigm transcend organizational and national boundaries?. American psychologist, 52(2), 130.

Bass, B. M., \& Avolio, B. J. (1993). Transformational leadership and organizational culture. Public administration quarterly, 112-121.

Bass, B. M., \& Riggio, R. E. (2006). Transformational leadership. Psychology Press.

Birasnav, M., Rangnekar, S., \& Dalpati, A. (2010). Transformational leadership, interim leadership , and employee human capital benefits: an empirical study. Procedia-Social and Behavioral Sciences, 5(2), 1037-1042. https://doi.org/10.1016/j.sbspro.2010.07.232

Boehm, S., Dwertmann, D., \& Bruch, H. (2015). The missing link? Investigating organizational identity strength and transformational leadership climate as mechanisms that connect CEO charisma with firm . The Leadership Quarterly. Retrieved from http://www.sciencedirect.com/science/article/pii/S1048984314000824

Burns, J. M. (1978). Leadership. New York. NY: Harper and Row Publishers.

Carless, S. A. (1998). Gender differences in transformational leadership: An examination of superior, leader, and subordinate perspectives. Sex roles, 39(11-12), 887-902.

Castanheiraa, P., \& Costa ${ }^{a}$, J. A. (2015). In search of transformational leadership : a ( Meta ) analysis focused on the Portuguese reality. Procedia - Social and Behavioral Sciences, 15(2011), 20122015. https://doi.org/10.1016/j.sbspro.2011.04.045

Chatterjee, A., \& Kulakli, A. (2015). An Empirical Investigation of the Relationship Between Emotional Intelligence, Transactional and Transformational Leadership Styles in Banking Sector. Procedia Social and Behavioral Sciences, 210, 291-300. https://doi.org/10.1016/j.sbspro.2015.11.369

Ebrahimi, P., Moosavi, S. M., \& Chirani, E. (2016). Relationship between Leadership Styles and Organizational Performance by Considering Innovation in Manufacturing Companies of Guilan Province. Procedia - Social and Behavioral Sciences, 230(May), 351-358. https://doi.org/10.1016/j.sbspro.2016.09.044

Esfahani, N., \& Soflu, H. G. (2011). Relationship between emotional intelligence and transformational leadership in physical education managers. In Procedia - Social and Behavioral Sciences (Vol. 30, pp. 2384-2393). https://doi.org/10.1016/j.sbspro.2011.10.465

García-Morales, V. J., Jiménez-Barrionuevo, M. M., \& Gutiérrez-Gutiérrez, L. (2012). Transformational leadership influence on organizational performance through organizational learning and innovation. Journal of business research, 65(7), 1040-1050.

García-Guiu, C., Moya, M., Molero, F., \& Moriano, J. A. (2016). Transformational leadership and group potency in small military units: The mediating role of group identification and cohesion. Journal of Work and Organizational Psychology, 4-11. https://doi.org/10.1016/j.rpto.2016.06.002

Gill, A. S., Flaschner, A. B., \& Shachar, M. (2006). Mitigating stress and burnout by implementing transformational-leadership. International Journal of contemporary hospitality 
INTERNATIONAL JOURNAL OF ACADEMIC RESEARCH IN BUSINESS AND SOCIAL SCIENCES

Vol. 9, No. 3, March, 2019, E-ISSN: 2222-6990 @ 2019 HRMARS

management, 18(6), 469-481.

Gökalp, M., Akdenk, M., Kalafat, T., \& Mente, S. (2010). The associations between university students ' transformational leadership characteristics and dysfunctional limitedness perceptions. Procedia-Social and Behavioral Sciences, 9, 132-136. https://doi.org/10.1016/j.sbspro.2010.12.125

Gözükara, I.., \& Şimşek, O. F. (2015). Linking Transformational Leadership to Work Engagement and the Mediator Effect of Job Autonomy: A Study in a Turkish Private Non-Profit University. Procedia - Social and Behavioral Sciences, 195, 963-971.

https://doi.org/10.1016/j.sbspro.2015.06.274

Gumusluoglu, L., \& Ilsev, A. (2009). Transformational leadership, creativity, and organizational innovation. Journal of business research, 62(4), 461-473.

Indrawati, N. K. (2014). Management by Inspiration: Implementation of Transformational Leadership on Business at Pondok Pesantren*) Sunan Drajat. Procedia - Social and Behavioral Sciences, 115(licies 2013), 79-90. https://doi.org/10.1016/j.sbspro.2014.02.417

İşcan, Ö. F., Ersarı, G., \& Naktiyok, A. (2014). Effect of Leadership Style on Perceived Organizational Performance and Innovation: The Role of Transformational Leadership Beyond the Impact of Transactional Leadership - An Application among Turkish SME's. Procedia-Social and Behavioral Sciences, 150, 881-889. https://doi.org/10.1016/j.sbspro.2014.09.097

Jansen, J. J., Vera, D., \& Crossan, M. (2009). Strategic leadership for exploration and exploitation: The moderating role of environmental dynamism. The Leadership Quarterly, 20(1), 5-18.

Jantzi, D., \& Leithwood, K. (1996). Toward an explanation of variation in teachers' perceptions of transformational school leadership. Educational Administration Quarterly, 32(4), 512-538.

Jati, M. K. K., Hassan, S., Harman, M. H., Jabar, S. A., \& Majid, M. A. A. (2015). Transformational Leadership and Organizational Culture: A Case of MAHB. Procedia Economics and Finance, 31(15), 425-435. https://doi.org/10.1016/S2212-5671(15)01217-4

Jordan, J., and Cartwright, S. 1998. Selecting expatriate managers: Key traits and competencies, Leadership and Organization Development Journal19(2), 89-96.

Kazmi, S. A. Z., \& Naaranoja, M. (2015). Innovative Drives Get Fuel from Transformational Leadership's Pied Pipers' Effect for Effective Organizational Transformation! Procedia - Social and Behavioral Sciences, 181, 53-61. https://doi.org/10.1016/j.sbspro.2015.04.865

Keow, T. (2011). Social and The Effect of Transformational Leadership on School Culture in Male' Primary Schools Maldives. Procedia - Social and Behavioral Sciences, 30, 2575-2580. https://doi.org/10.1016/j.sbspro.2011.10.503

Khany, R., \& Ghoreishi, M. (2014). One the Relationship between Teachers' Sense of Responsibility and Transformational Leadership Style. Procedia - Social and Behavioral Sciences, 136, 302-307. https://doi.org/10.1016/j.sbspro.2014.05.333

Khoshlahn, M., \& Sattari, F. (2016). The Role of Organizational Agility and Transformational Leadership in Service Recovery Prediction. Procedia - Social and Behavioral Sciences, 230(May), 142-149. https://doi.org/10.1016/j.sbspro.2016.09.018

Kim, S., \& Kim, J. (2014). Integration Strategy, Transformational Leadership and Organozational Commitment in Korea's Coorporate Split-offs. Procedia - Social and Behavioral Sciences, 109, 1353-1364. https://doi.org/10.1016/j.sbspro.2013.12.637 
INTERNATIONAL JOURNAL OF ACADEMIC RESEARCH IN BUSINESS AND SOCIAL SCIENCES

Vol. 9, No. 3, March, 2019, E-ISSN: 222 2-6990 @ 2019 HRMARS

Ling, S., \& Ling, M. (2016). The Influence of Transformational Leadership on Teacher Commitment towards Organization, Teaching Profession , and Student Learning in Secondary Schools in Miri , Sarawak ,. EDUCARE, 4(2), 155-178. Retrieved from http://www.mindamasjournals.com/index.php/educare/article/view/254/0

Mei, X., \& Ying, W. (2015). The Mediating Role of Psychological Empowerment between Transformational Leadership and Employee Work Attitudes. Procedia - Social and Behavioral Sciences, 172, 184-191. https://doi.org/10.1016/j.sbspro.2015.01.353

Mirkamali, S. M., Thani, F. N., \& Alami, F. (2011). Examining the role of transformational leadership and job satisfaction in the organizational learning of an automotive manufacturing company. Procedia - Social and Behavioral Sciences, 29, 139-148.

https://doi.org/10.1016/j.sbspro.2011.11.218

Muenjohn, N., \& Armstrong, A. (2015). Transformational leadership: The influence of culture on the leadership behaviours of expatriate managers. International Journal of Business and Information. Retrieved from http://52.68.60.251/ojs/index.php/ijbi/article/view/22

Olcum, M., \& Fayda, F. S. (2015). An analysis of academic leadership behavior from the perspective of transformational leadership. Procedia - Social and Behavioral Sciences, 207, 519-527. https://doi.org/10.1016/j.sbspro.2015.10.122

Pourbarkhordari, A., Hua, E., Zhou, I., \& Pourkarimi, J. (2016). How Individual-focused Transformational Leadership Enhances Its Influence on Job Performance through Employee Work Engagement. International Journal of Business and Management, 11(2), 249-261. https://doi.org/10.5539/ijbm.v11n2p249

Qu, R., Janssen, O., \& Shi, K. (2015). Transformational leadership and follower creativity: The mediating role of follower relational identification and the moderating role of leader creativity expectations. The Leadership Quarterly. Retrieved from http://www.sciencedirect.com/science/article/pii/S1048984314001337

Raj, A., Arokiasamy, A., Ghani, A., Abdullah, K., Zohir, M., Shaari, A., \& Ismail, A. (2016). Transformational Leadership Of School Principals And Organizational Health Of Primary School Teachers In Malaysia. Procedia - Social and Behavioral Sciences, 229, 151-157. https://doi.org/10.1016/j.sbspro.2016.07.124

Ross, J. A., \& Gray, P. (2006). Transformational leadership and teacher commitment to organizational values: The mediating effects of collective teacher efficacy. School effectiveness and school improvement, 17(2), 179-199.

Samad, S. (2012). The Influence of Innovation and Transformational Leadership on Organizational Performance. In Procedia - Social and Behavioral Sciences (Vol. 57, pp. 486-493). Elsevier B.V. https://doi.org/10.1016/j.sbspro.2012.09.1215

Selamat, N., Nordin, N., \& Anida, A. (2013). Rekindle Teacher' s Organizational Commitment : The Effect of Transformational Leadership Behavior. Procedia - Social and Behavioral Sciences, 90(InCULT 2012), 566-574. https://doi.org/10.1016/j.sbspro.2013.07.127

Sharma, P., Nagar, P., \& Pathak, S. C. (2012). Impact of Transformational Leadership on Creative Flexibility of Engineers in India. Procedia - Social and Behavioral Sciences, 57, 555-559. https://doi.org/10.1016/j.sbspro.2012.09.1224

Shin, S. J., \& Zhou, J. (2003). Transformational leadership, conservation, and creativity: Evidence from 
Korea. Academy of management Journal, 46(6), 703-714.

Tims, M., Bakker, A. B., \& Xanthopoulou, D. (2011). Do transformational leaders enhance their followers' daily work engagement? The Leadership Quarterly, 22(1), 121-131.

Wahab, S., Rahmat, A., Yusof, M. S., \& Mohamed, B. (2016). Organization Performance and Leadership Style: Issues in Education Service. Procedia - Social and Behavioral Sciences, 224, 593-598. https://doi.org/10.1016/j.sbspro.2016.05.447

Walumbwa, F. O., \& Lawler, J. J. (2003). Building effective organizations: Transformational leadership, collectivist orientation, work-related attitudes and withdrawal behaviours in three emerging economies. International journal of human resource management, 14(7), 1083-1101.

Yıldırım, N., \& Birinci, S. (2013). Impacts of Organizational Culture and Leadership on Business Performance: A Case Study on Acquisitions. Procedia - Social and Behavioral Sciences, 75, 7182. https://doi.org/10.1016/j.sbspro.2013.04.009

Zeinabadi, H., \& Rastegarpour, H. (2010). Factors affecting teacher trust in principal : testing the effect of transformational leadership and procedural justice. Procedia-Social and Behavioral Sciences, 5(2), 1004-1008. https://doi.org/10.1016/j.sbspro.2010.07.226

Zhang, X., Li, N., Ullrich, J., \& van Dick, R. (2015). Getting Everyone on Board: The Effect of Differentiated Transformational Leadership by CEOs on Top Management Team Effectiveness and Leader-Rated Firm Performance. Journal of Management, 41(7), 1898-1933. https://doi.org/10.1177/0149206312471387 